\title{
The electronic microscope analysis used to study the martensite morphology in high strength low alloy steels
}

\author{
M. ISAC
}

Polytechnic Institute of Bucharest, P.O. Box 39-111, 73200 Bucharest, Romania

\section{ABSTRACT}

The class of HSLA steels have a great development due to the spread of quenched and tempered steels.

The present paper has in view the research by means of electronic microscope analysis of structural characteristics of a HSLA steel after quenching and tempering.

The martensite-bainite structure is investigated by means of secondary electrons images, transmitted electrons images or by diffraction of electrons on selected areas.

Martensite has an aspect in slats, it is made up of packets with a high dislocation density. The martensite packets are made up of subgrains with slight differences of orientation among them, having the form of a thin blade with depth of $0.1 \mu \mathrm{m}$.

At the tempering over $450^{\circ} \mathrm{C}$ begin the loss of carbide coherence and the advanced decomposition of the qunching structure. Between $450^{\circ} \mathrm{C}$ and $600^{\circ} \mathrm{C}$ in the bainite cristal the ferrite cells become more evident. There appear subgrains with limits at the short angles. Gradually as the subgrains grow in the ferrite poliangled matrix appears limits for the big angles. There starts the matrix recrystallisation. In this stage these can be noticed a powerful growth of the alloy elements precipitates.

The electronic microscope analysis allowed the study of the evolution of morphologycal aspects of the martensite-bainite duplex structure leading to an efficiet use of this tipe of steel. 
The class of high strength low alloyed and microalloyed steels, called HSLA, is increasingly developing now; this development is also determined by a large use of quenched and tempered steels.

First of all, for using this type of steels, we have to learn about the connection between their structure and properties, in order to use efficiently the specific strenghtening mechanisms.

- solid solution hardening, in austenite, in tempered martensite or in ferrite

- hardening by increasing the density of the defects that consist in hardening by dislocations and hardening by grain boundaries.

- hardening by particles (precipitates) of alloying and microalloying elements in austenite, tempered martensite and ferrite.

The development of modern research means of structure by electonic microscopy, the comprehension of presence and dislocations movements effects during the alloying and microalloying of these steels, represent the necessary conditions of this type of steels development.

This paper displays the structural characteristics of C-Mn-Cr-B-V-steel (Table 1).

Table No1

The chemical composition of C-Mn-Cr-Mo-V steel

\begin{tabular}{cccccccccccc}
\hline \multicolumn{11}{c}{ Chemical composition (wt. \%) } \\
\hline $\mathrm{C}$ & $\mathrm{Mn}$ & $\mathrm{Si}$ & $\mathrm{S}$ & $\mathrm{P}$ & $\mathrm{Cr}$ & $\mathrm{Mo}$ & $\mathrm{B}$ & $\mathrm{Al}$ & $\mathrm{V}$ & $\mathrm{Ni}$ \\
\hline 0.2 & 1.00 & 0.35 & 0.019 & 0.018 & 0.98 & 0.41 & 0.008 & 0.006 & 0.006 & 0.72 \\
\hline
\end{tabular}

The steel structure after quenching in water at $920^{\circ} \mathrm{C}$ is made of martensite and inferior bainite.

From a crystalo-morphologic point of view martensite has a slats like aspect (called martensite of slats) with CVC network and containing the packets of great density of dislocation $\left(30-90 \mathrm{~cm}^{-2}\right)$.

The packets are of parallel slats ;each packet contains a matrix of slats with an identical orientation separate only by limits of sharp angles $\left(<20^{\circ}\right)$ and sets of slats with different orientation, separated from matrix by limits of large angles.

The singular martensite slats-like crystals cannot be noticed by optical microscopy research means, using them, one can just notice packets of $20 \mu \mathrm{m}$, in which one can distinguish parallel adjacent strips. By electronic microscopy one can remark the structure of the packets formed by subgrains with a slight difference in orientation, in the shape of their slats from $0.1 \mu \mathrm{m}$ to a few microns. Beside the slats-shaped martensite, after tempering in water of $\mathrm{Cr}-\mathrm{Mo}-\mathrm{B}-\mathrm{V}$ steel there also appears the inferior bainite.

This alloy gives a greater resilience to the steels as a completely martensite structure.

The structural determinations has been made with an electronic JEM C X JEOL microscope with an ASID scanning annex, with the resolution of the $2.04 \AA$, network, point- point $3.0 \AA$ resolution and possibilities to magnify 70-250,000 times.

We have used samples of $3 \mathrm{~mm}$ electrolytically thinned in a $20 \%$ percloric acid solution in ethylic alcohol at $30^{\circ} \mathrm{C}$ and $30 \mathrm{~V}$ working tension in a dynamic regime and $6 \mathrm{~V}$ static regime, in order to notice the foil by transmission and at 10-15 V tension, specific for determinations of electronic scanning microscopy. 
Fig $1 \mathrm{a}$ and $\mathrm{b}$ represent secondary electrons images made by primary scanning electrons beam of the areas of steel samples, quenched at $920^{\circ} \mathrm{C}$ in water. We have used a tension of accelerating the electrons of $60 \mathrm{kV}$. These images make evident the duplex inferior bainite-slats-shaped martensite.

Inside the needles of inferior bainite one can notice precipitates of rough carbides oriented at $60^{\circ}$ according to placket axis cast in a ferritic matrix of dark color (Figure 1). Berween the martensitic slats and their interior and on the bainite-martensite interfaces, as well we remark precipitates,thinner that those from bainite composition.

The morphologic type of slats-shaped martensite has been made evident by the transmission electronic microscope on thin foil, in light and dark field, as well as, by images obtained by diffraction of electrons on selected areas (Figure 2).

In Figure 2a, b and b' there are presented images of transmitted electrons magnified 20,000 times, as well as, images of electronic diffraction of selected areas, made on samples of quenched steel at $920^{\circ} \mathrm{C}$ in water; these determinations have been made at a $120 \mathrm{kV}$ electrons acceleration tension.

The images obtained with transmitted electrons point out the alternative distribution of the martensitic slats (Figure 2a), as well as, a great density of this type of dislocations specific for this martensite.

The circular images of electronic diffraction made of concentric rings are characteristic for martensite. By the electronic diffraction on selected areas, the $\mathrm{Fe}_{2.4} \mathrm{C}$ carbide from inferior bainite (Figure $2 \mathrm{~b}, \mathrm{~b}^{\prime}$ ), are presented.

The alloying and microalloying elements from the presented steel influence the kinetics of processes which take place in tempering, prolonging them so that the loose of carbide coherence and the great decomposition of the quenching structures by the formation of equilibrium $\mathrm{Fe}_{3} \mathrm{C}$ carbide take place starting from $450^{\circ} \mathrm{C}$ when also starting the processes of recrystalization in matrix.

The bainite decomposition also accurs at $450^{\circ} \mathrm{C}$ temperature;in bainite cristals there appear cells with density of dislocations, law in the center, high at the edge, as an effect of the matrix polygonization.

The rising of the temperature between $450-600^{\circ} \mathrm{C}$ in the bainite crystal, the ferrite cells become more distinct, their dimensions enlarge (there are subgrains, free or almost free of dislocation).

While the subgrains increase themselves it is possible to appear limits at the big-ended in the polygonized ferrite matrix; this means the begining of the first recristalization of matrix.

In Figure 3 there are images of secondary electrons, made by a primary scanning electrons beam of the steel samples quenched at $920^{\circ} \mathrm{C}$ in water and tempered at $640^{\circ} \mathrm{C} / 90^{\prime} /$ air, using a tension of acceleration of $60 \mathrm{kV}$.

In Figure 4 there are a secondary electrons image made of the samples of quenched steel at $920^{\circ} \mathrm{C}$ and tempered at $700^{\circ} \mathrm{C} / 90^{\prime} /$ air, at $100 \mathrm{kV}$ tension of acceleration of electrons.

After tempering at $570^{\circ} \mathrm{C}$ one can clearly see the precipitation of alloying and microalloying elements, precipitate oriented and represented by rough carbides distributed on the former austenite grains limits. The tempering at $700^{\circ} \mathrm{C}$ points out the coalescence of precipitates, carbides and nitrides of $\mathrm{B}, \mathrm{V}, \mathrm{Al}$, as well as, chrome carbide $\left(\mathrm{Cr}_{7} \mathrm{C}_{3}, \mathrm{Cr}_{23} \mathrm{C}_{6}\right)$ and Molybdenum [(FeMo $\left.{ }_{23} \mathrm{C}_{6}\right]$.

In Figure 5 there are presented the following images (for the quenched steel at $930 \mathrm{C} /$ water and tempered at $700^{\circ} \mathrm{C} / 90^{\prime} /$ air):

a - images of secondary electrons, obtained by scanning at accelerating tension of $100 \mathrm{kV}$. 
b - images of transmitted electrons at accelerating tension of $120 \mathrm{kV}$

c - images of electronic diffraction on a selected area which emphasize the ferritic phase representing the matrix, respectively $\mathrm{Cr}_{23} \mathrm{C}_{6}$ carbide.

After tempering at $700^{\circ} \mathrm{C}$, the coalescence phenomenon of carbides and recrystalization of ferrite are made evident (Figure 5a).

The image of trasmitted electrons (Figure $5 \mathrm{~b}$ ) shows a great density of precipitates distributed in ferritic matrix.

In the image of electrons diffraction, obtained on a selected area, with circular aspect, corresponding to ferrite, we have identified position in the image of solid solution diffraction due to the $\mathrm{M}_{23}(\mathrm{~B}, \mathrm{C})_{6}$ carbide (Figure 5a).

The electronic microscope analyse permits the minute study of the martensite and bainite morphologic type in the C-Cr-Mo-B-V quenched steel structure, the study of sorbite structure obtained by tempering and the following of the precipitation processes of alloying and microalloying elements in bainite-martensitic or ferritic matrix.

\section{BIBLIOGRAPHY}

[1] .ISAC M., Doctoral paper, Pol.Inst.of Bucharest, 1986.

[2] TILKIN M.A.,Structural Steel Structure, Metallurghia, Moskva, 1983.

[3] NISHIYAMA Z., Martensitic Transformation, Academic Press, New-York, 1978. 

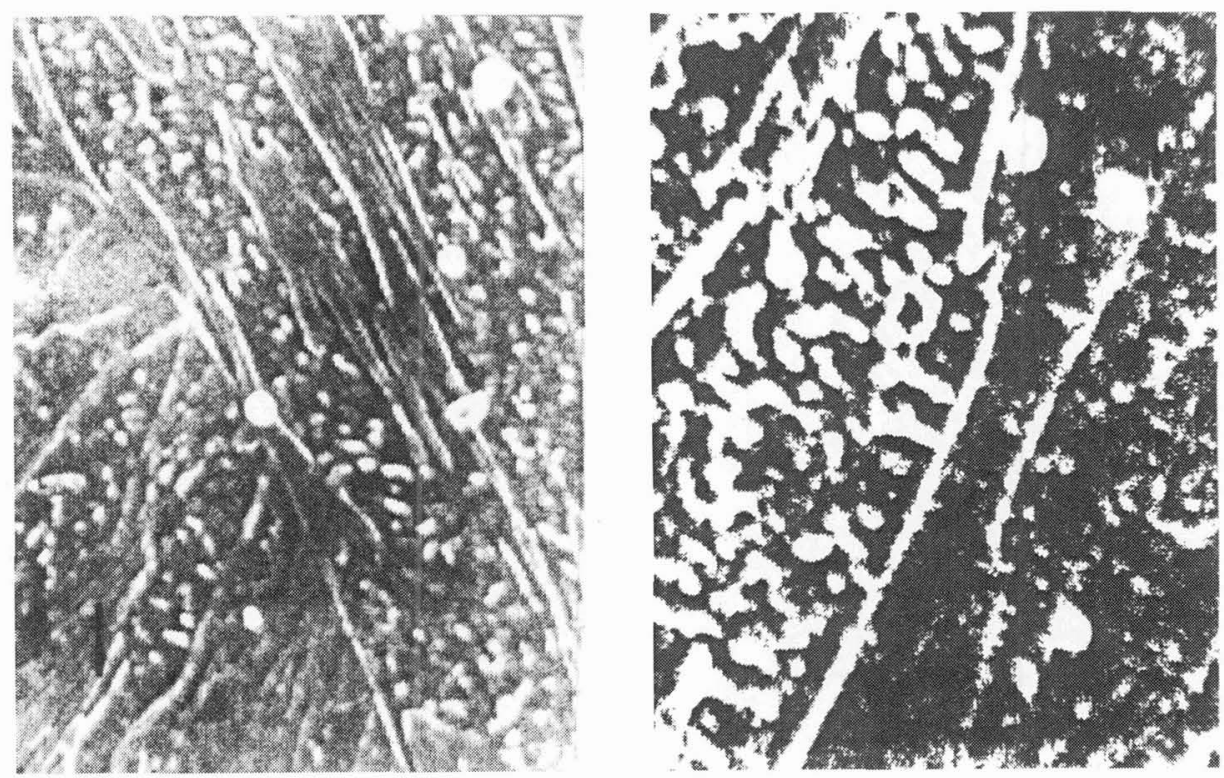

Figure 1 Secondary electrons images made by a primary scanning electrons beam of quenched samples; a) 20,000:1; b) $50,000: 1$.
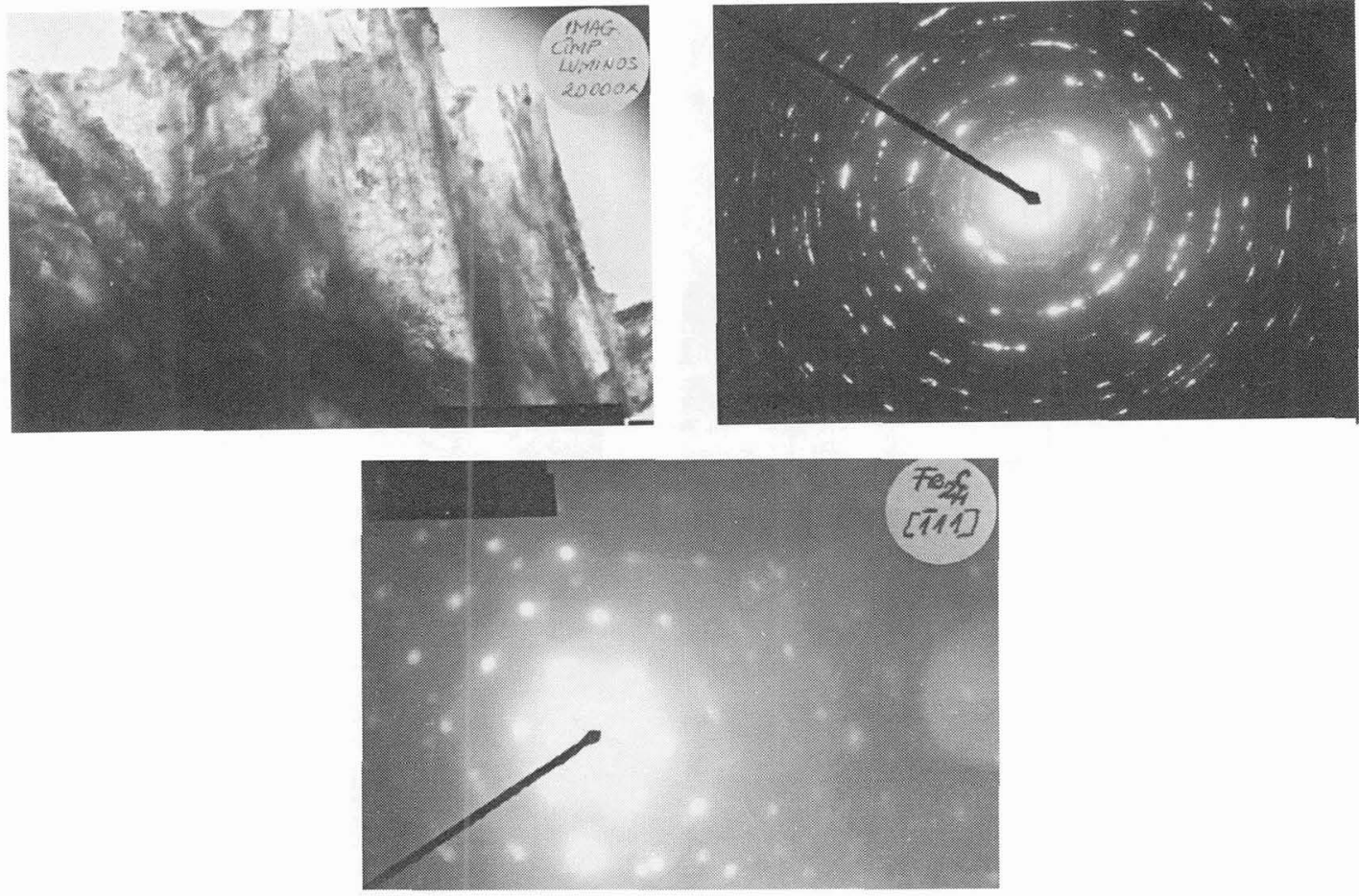

Figure 2 Images of electronic microscopy on thin foils

a) image obtained by transmitted electrons,

b), b') images obtained by diffraction of electrons. 


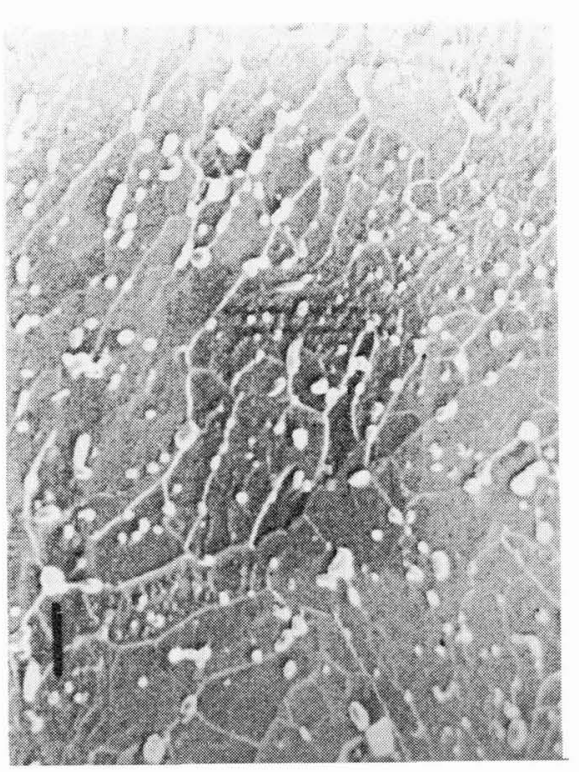

Figure 3 Image of scanning electron microscopy magnified 15,000:1.

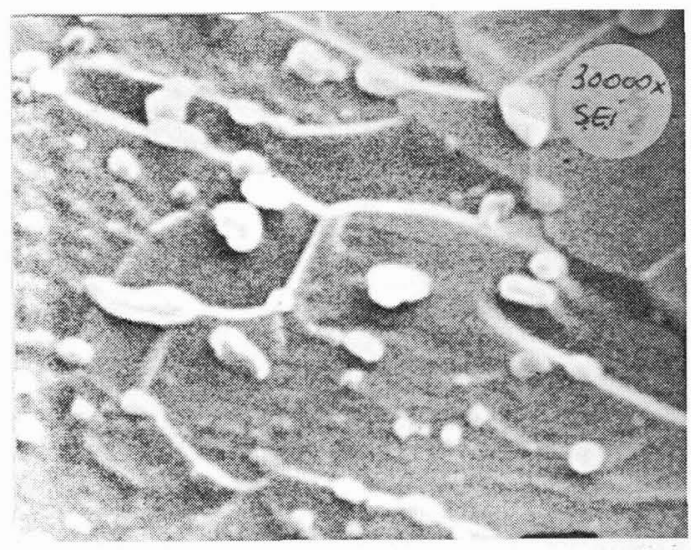

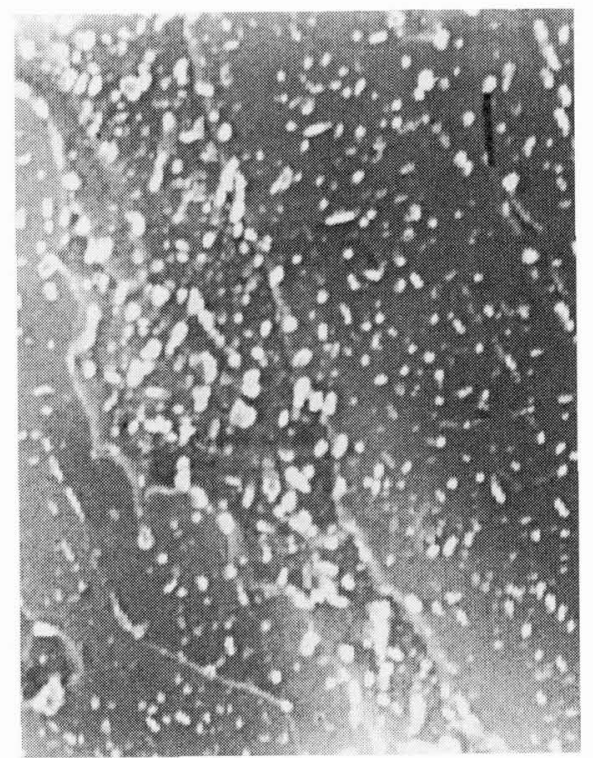

Figure 4 Image of scanning electron microscopy magnified 10,000:1.

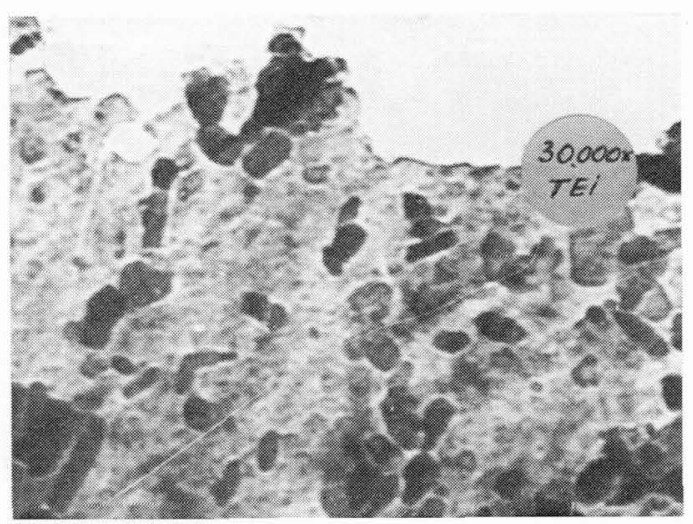

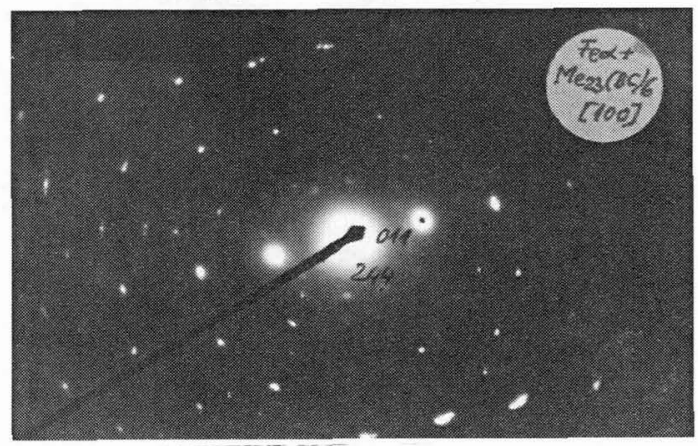

Figure 5 Images of electron microscopy obtained by:

a) scanning; $30,000: 1$

b)transmission; 30,000:1

c)diffraction of electrons 